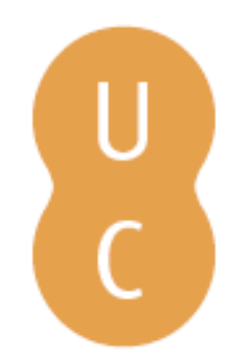

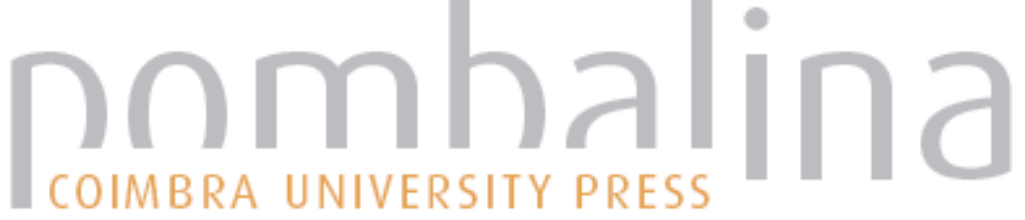

\section{Fire as a tool to manage pollination services}

Autor(es): $\quad$ Brown, Julian; Christie, Fiona; York, Alan

Publicado por: Imprensa da Universidade de Coimbra

URL

persistente: URI:http://hdl.handle.net/10316.2/34188

DOI: $\quad$ DOI:http://dx.doi.org/10.14195/978-989-26-0884-6_62

Accessed : $\quad$ 26-Apr-2023 02:05:47

A navegação consulta e descarregamento dos títulos inseridos nas Bibliotecas Digitais UC Digitalis, UC Pombalina e UC Impactum, pressupõem a aceitação plena e sem reservas dos Termos e Condições de Uso destas Bibliotecas Digitais, disponíveis em https://digitalis.uc.pt/pt-pt/termos.

Conforme exposto nos referidos Termos e Condições de Uso, o descarregamento de títulos de acesso restrito requer uma licença válida de autorização devendo o utilizador aceder ao(s) documento(s) a partir de um endereço de IP da instituição detentora da supramencionada licença.

Ao utilizador é apenas permitido o descarregamento para uso pessoal, pelo que o emprego do(s) título(s) descarregado(s) para outro fim, designadamente comercial, carece de autorização do respetivo autor ou editor da obra.

Na medida em que todas as obras da UC Digitalis se encontram protegidas pelo Código do Direito de Autor e Direitos Conexos e demais legislação aplicável, toda a cópia, parcial ou total, deste documento, nos casos em que é legalmente admitida, deverá conter ou fazer-se acompanhar por este aviso.

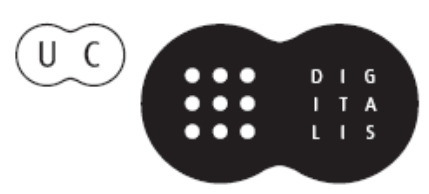




\section{ADVANCES IN}

Forest Fire

\section{RESEARCH}

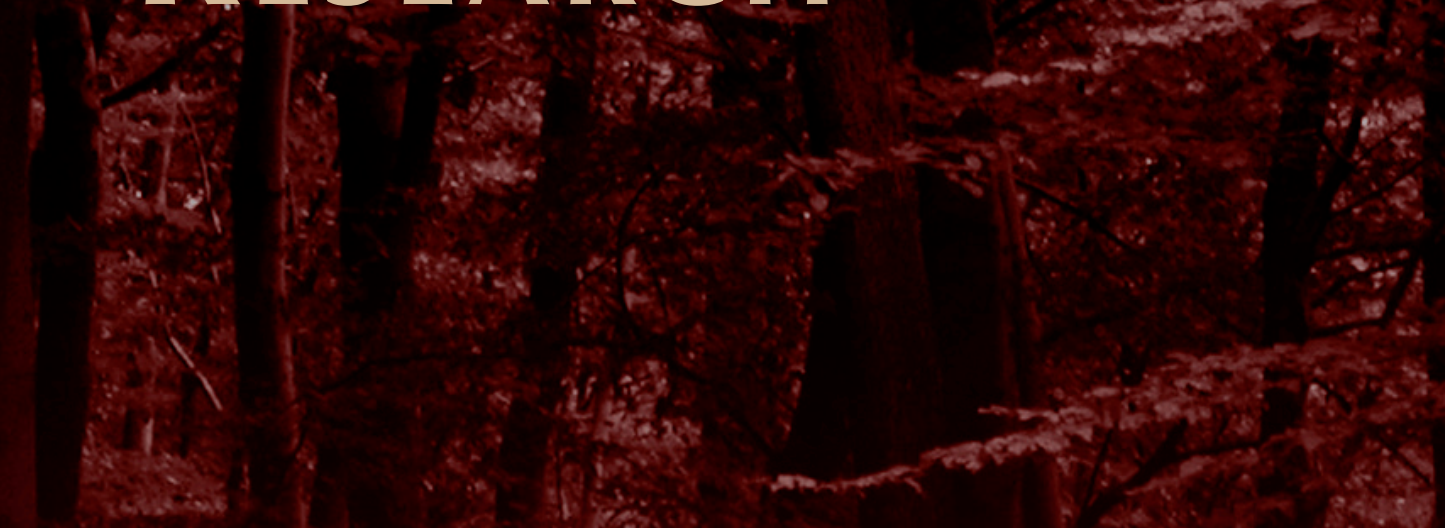

\section{DOMINGOS XAVIER VIEGAS}

\section{EDITOR}




\title{
Fire as a tool to manage pollination services
}

\author{
Julian Brown ${ }^{\mathrm{a}}$, Fiona Christie ${ }^{\mathrm{a}}$, Alan York $^{\mathrm{a}}$ \\ ${ }^{a}$ University of Melbourne, Department of Forest and Ecosystem Science, Creswick Campus, 4 Water \\ Street, Creswick, VIC, 3363, j.brown3@student.unimelb.edu.au
}

\begin{abstract}
As a tool of land management and conservation there are a number of applications for which fire is poorly developed. One of those applications is the management of ecosystem services such as pollination and pest control that are provided by mobile organisms. Pollination in particular is an ecosystem service that requires improved management, in response to global declines in pollinators that present a threat to the plants that are dependent on them for reproduction. Much recent attention has been given to the effects of land use and land management generally on pollination, but little to fire as a particular form of land management. Here we develop a conceptual model describing hypothesised causal chains linking fire to pollination, and then report the initial findings of a study investigating fire effects on pollination as informed by this model for an orchid species native to Australia.
\end{abstract}

Keywords: pollination, Caladenia tentaculata, fire, succession.

\section{Introduction}

Fire is a tool with a wide variety of applications in land management and conservation. One potential application that has received little attention is as a means to manage ecosystem services provided by mobile organisms, such as pollination and pest control. Fire can influence the population and community dynamics of mobile organisms (Whelan et al. 2002), so it might be used to manage the services they provide. There is an urgent need to improve management of pollination services as recent declines in pollinators across the globe (including fire-prone regions) raises concerns over the loss of pollination services to crops and wild plant populations (Potts et al. 2010; Vanbergen and IPI 2013). Pollinators and consequently pollination services are affected by habitat conditions at the landscapescale (Kremen et al. 2007) and fire is a relatively inexpensive tool for managing habitat at this scale. Recent research has indeed demonstrated the role of fire in structuring pollinator communities through habitat alteration (e.g. Potts et al. 2003a, b, 2005, 2006). However, pollination rate can be determined by factors other than pollinator population and community dynamics (Kremen et al. 2007); so it is important to consider whether fire might influence pollination through additional pathways to avoid unintended consequences of management. No single study has considered all the possible pathways through which fire might influence pollination.

A conceptual model describing hypothesised causal chains linking fire to pollination is developed here to guide research into the effects of fire on pollination. A general model of the effects of land use and land management on pollination has recently been developed (Kremen et al. 2007) and underpinned a recent quantitative model of pollination services across landscapes that performed well when evaluated against independent data (Lonsdorf et al. 2009). Within this tested framework the conceptual model of interactions between fire (as a particular component of land management) and pollination services is developed by combining the body of research in pollination ecology underlying Kremen et al.'s model with the relevant body of research in fire ecology. Kremen et al. propose that land use/management influences pollination by affecting the target plant to which pollination services are of interest (at the individual, patch, and population level), the plant community (with which the target plant interacts in competition or facilitation through shared pollinators), the pollinator community, and the biotic and abiotic factors that influence these groups. The model developed here (Figure 1) 
describes the mechanisms (Blue boxes) linking fire (Orange box) to groups (Green boxes) to pollination (Yellow box). The mechanisms linking fire to groups can be direct (e.g. direct mortality) or indirect (e.g. alteration of nesting sites) effects that are immediate and/or occur along a time-sincelast-fire trajectory (Dafni et al. 2012).

Kremen et al. (2007) highlight the importance of both local-scale changes in groups and their aggregation into landscape structure in influencing pollination. That is, there are multiple spatial scales at which changes in groups can influence pollination, which might be of particular relevance to fire management of pollination services. For example, flower visitation by bumblebees is related to the abundance of co-flowering plants within an area of $100-500 \mathrm{~m}^{2}$, but not at larger or smaller scales (Thomson 1981; Johnson et al. 2003). Flower visitation by bumblebees is related to bumblebee habitat conditions within an area several orders of magnitude larger, corresponding to the bumblebees' home range (Westphal et al. 2006). The implication is that the size of a fire might determine its impact on pollination by determining the degree to which different pathways influencing pollination are affected; a fire that is $500 \mathrm{~m}^{2}$ might alter competition or facilitation for pollination with little effect on pollinator populations, whereas a larger fire might impact both.

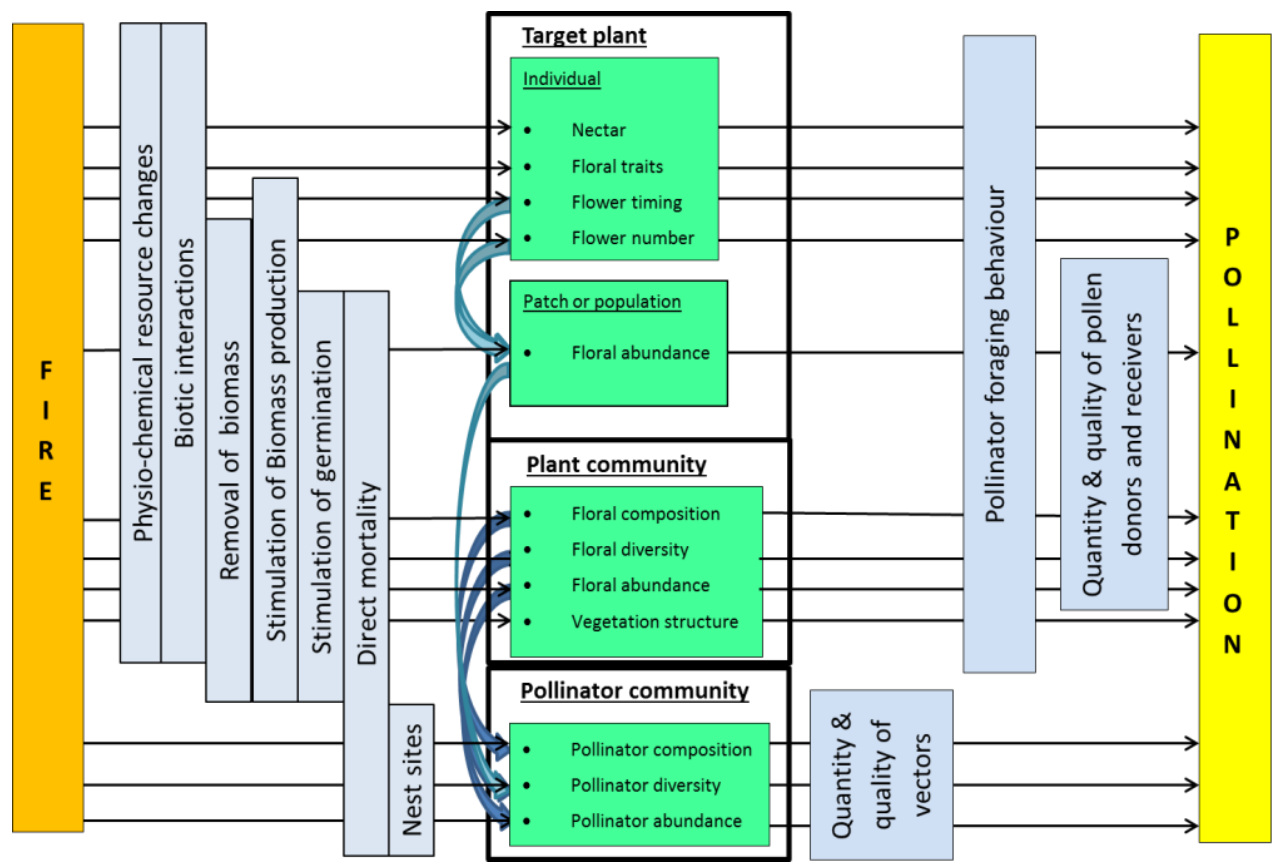

Figure 1. Conceptual model outlining hypothesised pathways of the relationships between fire and pollination. Fire may influence groups (Green boxes) through a range of mechanisms (Blue boxes). Groups may influence pollination directly (black arrows) or indirectly via a number of biotic interactions (blue arrows) through a second set of mechanisms (Blue boxes).

This model has been used to guide a PhD research project (J. Brown) into the effects of fire on pollination in a species of the Orchidaceae family (Caladenia tentaculata). There is a need to learn about fire effects on pollination in orchids because many inhabit fire-prone environments across the globe (Naveh et al. 1994; Swarts and Dixon 2009; Lamont and Downes 2011) and fecundity is generally limited by pollen (Trembley et al. 2005). A group of particular concern in Australia is the sexually-deceptive orchids that achieve pollination through mimicry of the sex pheromones of female insects. They occur in some of the most flammable ecosystems in the country (e.g. heathy woodlands) and are one of the most pollen-limited orchid groups (Tremblay et al. 2005; Phillips et al. 2009). The critically threatened status of a number of sexually-deceptive orchids has been attributed to the highly specialised, and so sensitive to ecological change, pollination system characteristic of this group (Swarts and Dixon 2009). Many sexually-deceptive along with other groups of terrestrial orchids are 
stimulated to flower by fire (Jones 2006; Coates and Duncan 2009; Duncan 2012), and the promotion of flowering and emergence through regular burning is a common management recommendation for these plants (Cropper et al. 1989; Lunt 1994; Coates et al. 2006; Coates and Duncan 2009). However, the effects of fire on pollination through any of the possible pathways is unknown, so there is no way of predicting the effect of regular burning on pollination and determining to what extent this will depend on fire size. Reported here are the findings from the pilot study of a PhD project (J. Brown) investigating the effects of fire on pollination in the sexually-deceptive orchid C. tentaculata.

\section{Methods}

\subsection{Study System}

The study landscape was an area of approximately $15,000 \mathrm{~km}^{2}$ in south-west Victoria, Australia (Figure 2). The area encompassed the Grampians National Park and numerous forests on public land between the National Park and the South Australian border. The native vegetation consists of sclerophyllous heaths, shrub lands, and woodlands interspersed with open grasslands (Gibbons and Downes 1964; Dodson 2001). The area has a Mediterranean-type climate (hot dry summers and mild wet winters), and has experienced recurring fires throughout the Holocene (reviewed in Dodson 2001). Prescribed fire is currently applied to vegetation on public land in an attempt to protect lives and property and achieve ecological objectives (DEPI 2013a, b). The area was chosen because the orchid and its pollinator have been detected at a number of localities in this area (Bower 2009), there is a broad range of fire histories, and minimal topographic variation between sample locations. In order to cover a wide range of post-fire successional stages this research was based on a chronosequence of 52 heathy woodland sites ranging from several months since last fire to several decades since last fire.

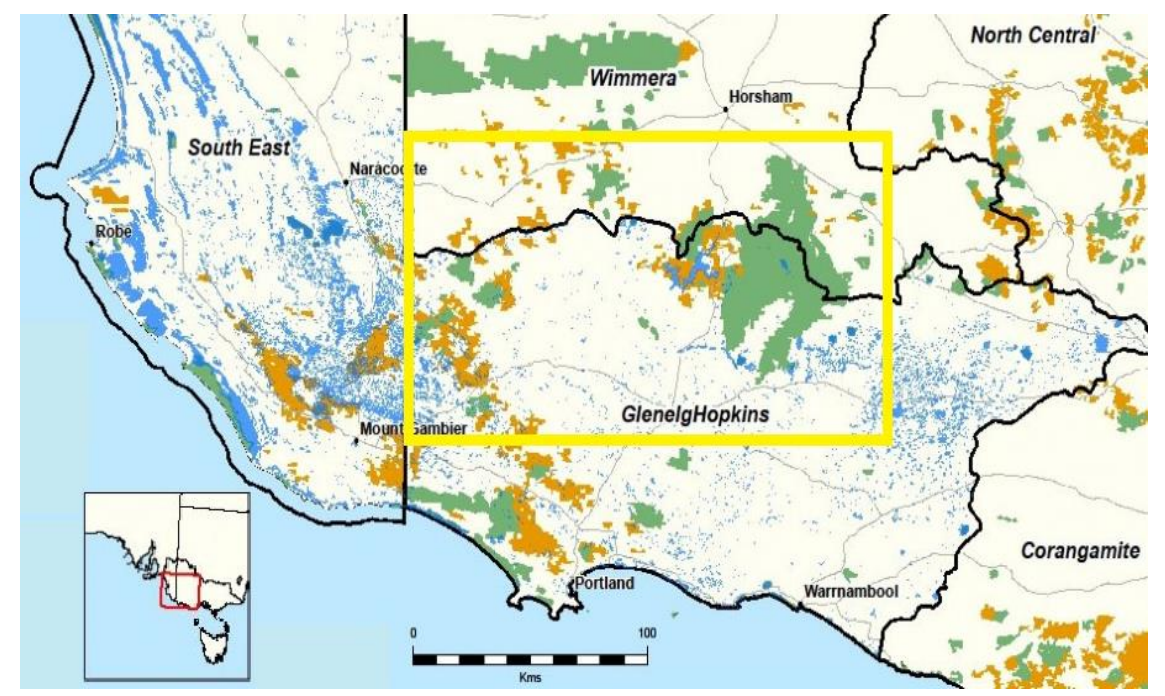

Figure 2. Area (yellow rectangle) of south-west Victoria within which all samples were collected. Green and brown areas are native vegetation (National Park and State Forest respectively), blue areas water bodies, and white rural and residential.

The native orchid $C$. tentaculata has been chosen for this study for a number of reasons. It is stimulated to flower by fire (Jones 2006; Duncan 2012). It is also known to be pollinated by a single species of parasitoid wasp from the thynnine subfamily - Thynnoides pugionatus - by sexual deceit (Peakall and Beattie 1996; Jones 2006). Both plant and pollinator are widespread and common in south-east Australia (Jones 2006; Bower 2009), allowing for relatively large sample sizes.

\subsection{Data collection}


The main response variable of interest was the visitation rate of $T$. pugionatus to $C$. tentaculata flowers. The pollinators of $C$. tentaculata respond rapidly to the presentation of its flowers (Peakall and Beattie 1996), so at each of the 52 sites four $C$. tentaculata flowers (growing in pots) were placed at a single location for 10 minutes and the number of times pollinators made contact with (visited) the flowers was observed (sexually-deceptive orchids typically exhibit one-to-one relationships with their pollinators and the pseudo-copulatory flower visiting behaviour is distinct [Gaskett 2011], such that pollinators could be identified by observing visitation). This was done multiple times at each site to allow for the development of a model that accounts for the probability of detecting the pollinator (i.e. number of visits being greater than zero) given its presence. Also obtained at each location was the time-since-last-fire (TSLF) at the site (sites 55 years or greater were classified as 55 years old which corresponds roughly to senescence for heathy woodlands [Cheal 2010] and the limits of accurate fire records for this region) from GIS layers provided by the Department of Environment and Primary Industries, temperature (since this is known to influence wasp activity) at the time of pollinator sampling, and for the recently burnt sites (less than three years before the time of sampling) the distance to the nearest edge of the burnt site (i.e. distance to nearest unburnt vegetation).

\subsection{Data analysis}

Only observations made above the critical temperature threshold for wasp activity of $17^{\circ} \mathrm{C}$ (determined using repeat observations at sites to model the probability of detecting the pollinator given its presence as a function of temperature, which is not presented here) were used for the analysis presented here. Zero visits were observed at a large proportion of the sites, so logistic regression was first used to model pollinator presence/absence (i.e. greater than zero visits/zero visits respectively) as a function of TSLF, and simple linear regression was used to model the maximum number of visits observed at each site where pollinators were present (that is, excluding sites where no pollinators were observed) as a function of TSLF. For the logistic regression, $\mathrm{R}^{2}$ was calculated using the method developed in Nakagawa and Schielzeth 2013). For the subset of the data corresponding to recently burnt sites, simple linear regression was used to model the maximum number of visits observed at each site as a function of distance to the nearest edge of the burnt site. All analyses were performed in the $\mathrm{R}$ statistical environment (R Development Core Team 2011).

\section{Results}

The model of pollinator presence/absence as a function of TSLF was a poor fit to the data $\left(\mathrm{R}^{2}=0.00\right)$. When the maximum number of $T$. pugionatus visits to $C$. tentaculata observed at each site was modelled as a linear function of TSLF, the model explained a negligible amount of the variation $\left(\mathrm{R}^{2}=\right.$ 0.02). The relationship between the maximum number of visits and TSLF is shown in Figure 3 below, and it can be seen that unusually high visitation values were observed in two very recently burnt sites and one long unburnt site, but that lower values were observed across all sites (thus explaining the poor model fit). 


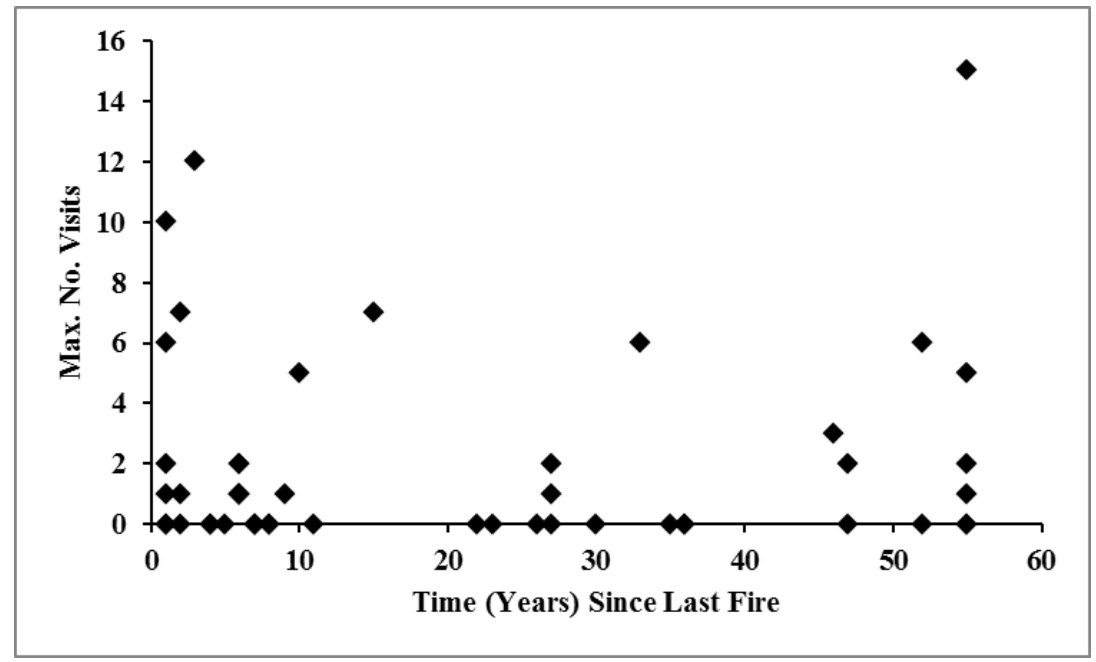

Figure 3. Show the maximum number of visits to C. tentaculata flowers by thynnine wasps at each site as a function of the number of years since the last fire at each site.

The model of the maximum number of visits to flowers at recently burnt sites as a linear function of distance from the nearest edge of the burn site was also a poor fit to the data $\left(\mathrm{R}^{2}=0.00\right)$. Figure $4(\mathrm{a})$ shows that this can be attributed to an extreme outlier. With this outlier removed (Figure 4(b)), model fit improved substantially $\left(\mathrm{R}^{2}=0.45\right)$. Inspection of Figure $4(\mathrm{~b})$ suggests that inclusion of polynomial terms would further enhance model fit, though there were not enough observations to allow the addition of further parameters.

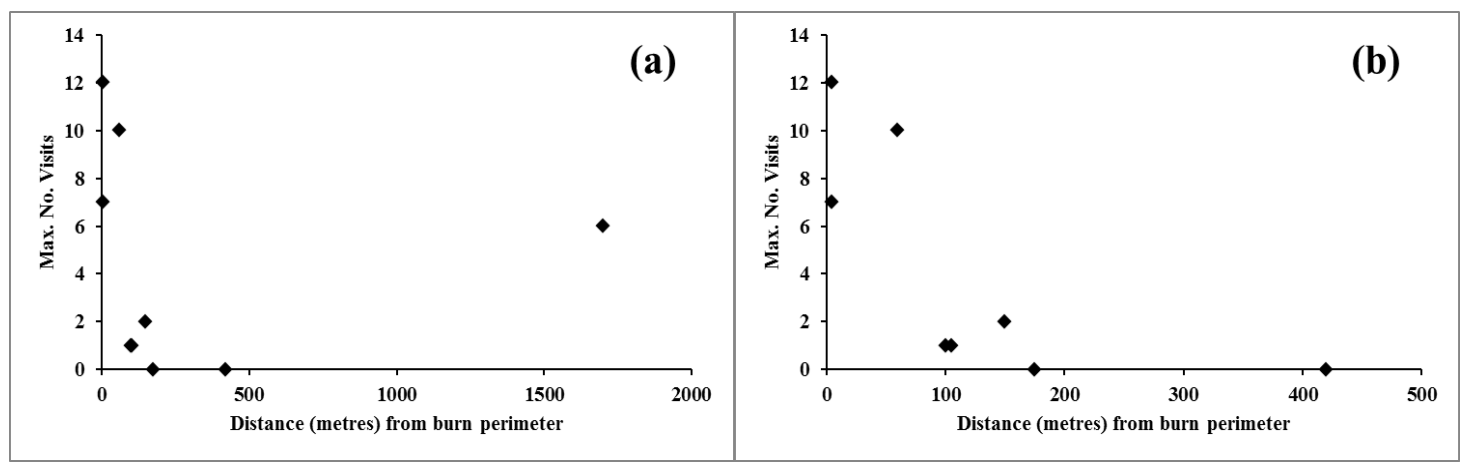

Figure 4. Shows the maximum number of visits to C. tentaculata flowers by thynnine wasps at (a) each recently burnt site and (b) each recently burnt site except for the outlier site, as a function of the distance of the flowers from the nearest edge of the burn site

\section{Discussion}

Statistical models developed here were generally poor fits to the data. Pollinator presence or visitation rate showed no clear relationship with TSLF, and visitation rate in recently burnt sites only showed a relationship to distance from the nearest edge of the burn site when an outlier was removed. The value of this pilot study lies in the potential explanations for the failure of fitted models to explain observed variation.

The outlier in the data pertaining to the recently burnt subset of sites is interesting. It lay approximately $1,700 \mathrm{~m}$ from the burn perimeter, which is well beyond the distance from the perimeter where the model without the outlier predicts zero visitation. It has been suggested that some thynnine wasps (the subfamily to which $T$. pugionatus belongs) might be capable of travelling up to 1,600 $\mathrm{m}$, but most are 
thought to be restricted to distances of $800 \mathrm{~m}$ (Ridsdill-Smith 1970) and the greatest distance $T$. pugionatus has been observed to travel between $C$. tentaculata flowers was $58 \mathrm{~m}$ (Peakall and Beattie 1996). Thus, either the observed outlier extends the known foraging range of thynnine wasps, or the wasps were resident in the recently burnt site. The TSLF GIS layer used in this analysis does not include information about variation in fire severity within fire perimeters, which may provide faunal refugia that allows fire-sensitive animals to be present immediately after fire (Whelan et al. 2002; Penman et al. 2007). Alternatively, the wasps are capable of rapidly recolonizing from surrounding unburnt vegetation or surviving the passage of fire of any severity.

Although models were generally poor fits to the data, the patterns observed are interesting in the context of the conceptual model developed in the introduction. From the patterns shown in Figure 3 and Figure 4(b) it would appear as though when $C$. tentaculata flowers in the early post-fire environment (as it tends to do) it is capable of attracting more visits from its pollinators compared to other post-fire seral stages (except perhaps for very long unburnt sites), provided it is not too far from unburnt vegetation. In other words, small fires centred on the orchid may enhance pollination, but as fire size increases the pollination benefits may eventually disappear such that visitation is equal to or less than what is experienced in later seral stages. Thus, the size of a fire may be important in determining its impact on $C$. tentaculata pollination. However, this requires more formal testing as the data presented here are suggestive at best.

Although this tentative model is yet to be tested, it is interesting to consider the underlying mechanisms. Petit and Dickson (2005) found that the pollination rate of a sexually-deceptive orchid decreased as the amount of vegetation within close proximity increased, which they attributed to increased difficulty for pollinators in locating orchid flowers. In the heathy woodland system studied in the present paper, vegetation structure is low in the early post-fire environment, gradually increasing to a maximum in mid successional stages, and then declining again late in succession (Cheal 2010; Brown 2013). Thus, the highest potential (depending on other factors such as perhaps distance from burn edge) pollination rates would be expected in recently burnt sites, and then again much later in succession, which is what was observed in the present study. A decrease in visitation in recently burnt sites with increasing distance from unburnt vegetation might occur if pollinators are incapable of inhabiting or otherwise avoid recently burnt sites, entering only when enticed by a signal (in this case indicating the possibility of a mating opportunity, since the orchids are sexual mimics) that presumably decreases in strength with greater distance from the source (the ability of an insect to detect a sex pheromone decreases as a logarithmic function of distance from the odour source [Andersson et al. 2012]). Further work is required to investigate these possible mechanisms in the study system.

The next stage of the $\mathrm{PhD}$ project is to explore some of the possible interpretations of the data presented here. The main focus will be on determining the relationship between visitation and distance from the edge of the burn site. Observations will be made of visitation to $C$. tentaculata flowers placed at a number of fixed distances from the fire perimeters of a number of recently burnt sites, and attempts will be made to control for burn severity. Processes operating at different spatial scales will also be explored. In particular, relationships between $C$. tentaculata pollination and vegetation structure (and co-flowering heterospecifics) measured within close proximity to the orchid, and between pollinator activity and seral stage composition at the landscape scale. Together the findings from this research will contribute to the knowledge base required to effectively use fire to manage C. tentaculata and other sexually-deceptive orchids with fire-stimulated flowering, which are among the most threatened in Australia (Victoria Flora and Fauna Guarantee Act 1988).

\section{Acknowledgements}

We would like to thank the Department of Environment and Primary Industry and the University of Melbourne for financial and technical support, Colin Bower and Garry French for training in the use 
of orchids to detect their pollinators, and Julio Najera, John Loschiavo, and Rowena Booth for assistance with data collection.

\section{References}

Andersson P, Löfstedt C and Hambäck PA (2012) How insects sense olfactory patches - the spatial scaling of olfactory information. Oikos 122, 1009-1016.

Brown T (2013) The effects of fire on invertebrate pollinator communities. Honours Thesis, University of Melbourne, Victoria, Australia.

Bower CC (2009) Pollinators of sexually deceptive spider orchids (Caladenia) in Victoria. Report to the Australian Orchid Foundation, Melbourne.

Cheal D (2010) Growth stages and tolerable fire intervals for Victoria's native vegetation data sets. Fire and Adaptive Management Report No. 84. Department of Sustainability and Environment, East Melbourne, Victoria, Australia.

Coates F and Duncan M (2009) Demographic variation between populations of Caladenia orientalis a fire-managed threatened orchid. Australian Journal of Botany 57, 326-339.

Coates F, Lunt I and Tremblay R (2006) Effects of disturbance on population dynamics of the threatened orchid Prasophyllum correctum D.L.Jones and implications for grassland management in south-eastern Australia. Biological Conservation 129, 59-69.

Cropper SC, Calder DM and Tonkinson D (1989) Thelymitra epipactoides F. Muell. (Orchidaceae): the morphology, biology and conservation of an endangered species. Proceedings of the Royal Society of Victoria 101, 89-101.

Dafni A, Izhaki I, and Ne'eman G (2012) The Effect of Fire on Biotic Interactions in Mediterranean Basin Ecosystems: Pollination and Seed Dispersal. Israel Journal of Ecology and Evolution 58(23), 235-250.

Department of Environment and Primary Industry (DEPI) (2013a) Fire Operations Plan 2013/142015/16 Barwon South West Region. Department of Environment and Primary Industries, Victoria, Australia, Melbourne.

Department of Environment and Primary Industry (DEPI) (2013b) Fire Operations Plan 2013/142015/16 Wimmera Region. Department of Environment and Primary Industries, Victoria, Australia, Melbourne.

Dodson JR (2001) Holocene vegetation change in the mediterranean-type climate regions of Australia. Holocene 11, 673-80.

Duncan M (2012) Response of Orchids to Bushfire: Black Saturday Victoria 2009 - Natural values fire recovery program. Department of Sustainability and Environment, Heidelberg, Victoria.

Gaskett AC (2011) Orchid pollination by sexual deception: pollinator perspectives. Biological Review $86,33-75$.

Gibbons F R and Downes RG (1964) A Study of the Land in South Western Victoria. Soil Conservation Authority, Victoria, Melbourne.

Johnson SD, Peter CI, Nilsson LA and Agren J (2003) Pollination success in a deceptive orchid is enhanced by co-occurring rewarding magnet plants. Ecology 84, 2919-2927.

Jones DL (2006) A complete guide to native orchids of Australia including the island territories. Reed New Holland, Sydney.

Kremen C, Williams NM, Aizen MA, Gemmill-Herren B, LeBuhn G, Minckley R, Packer L, Potts SG, Roulston T, Steffan-Dewenter I, Vázquez DP, Winfree R, Adams L, Crone EE, Greenleaf SS, Keitt TH, Klein AM, Regetz J and Ricketts TH (2007) Pollination and other ecosystem services produced by mobile organisms: a conceptual framework for the effects of land-use change. Ecology Letters 10(4), 299-314.

Lamont BB and Downes KS (2011) Fire-stimulated flowering among resprouters and geophytes in Australia and South Africa. Plant Ecology 212, 2111-2125. 
Lonsdorf E, Kremen C, Ricketts T, Winfree R, Williams N and Greenleaf S (2009). Modelling pollination services across agricultural landscapes. Annals of Botany 103, 1589-1600

Lunt ID (1994) Variation in flower production of nine grassland species with time since fire, and implications for grassland management and restoration. Pacific Conservation Biology 1, 359-366.

Nakagawa S and Schielzeth H (2013) A general and simple method for obtaining R2 from generalized linear mixed-effects models. Methods in Ecology and Evolution 4(2), 133-142.

Peakall R and Beattie AJ (1996) Ecological and genetic consequences of pollination by sexual deception in the orchid Caladenia tentaculata. Evolution 50, 2207-2220.

Penman TD, Kavanagh RP, Binns DL and Melick DR (2007) Patchiness of prescribed burns in dry sclerophyll eucalypt forests in south-eastern Australia. Forest Ecology and Management 252(1), 24-32.

Petit S and Dickson CR (2005) Grass-tree (Xanthorrhoea semiplana, Liliaceae) facilitation of the endangered pink-lipped spider orchid (Caladenia syn. Arachnorchis behrii, Orchidaceae) varies in South Australia. Australian Journal of Botany 53(5), 455-464.

Phillips R, Faast R, Bower C, Brown G and Peakall R (2009) Implications of pollination by food and sexual deception for pollinator specificity, fruit set, population genetics and conservation of Caladenia (Orchidaceae). Australian Journal of Botany 57, 287-306.

Potts SG, Vulliamy B, Dafni A, Ne'eman G, O'Toole C, Roberts S and Willmer P (2003a) Response of plant pollinator communities to fire: changes in diversity, abundance and floral reward structure. Oikos 101, 103-112.

Potts SG, Vulliamy B, Dafni A, Ne'eman G and Willmer P (2003b) Linking bees and flowers: how do floral communities structure pollinator communities? Ecology 84, 2628-2642.

Potts SG, Vulliamy B, Roberts S, O'Toole C, Dafni A, Ne'eman G and Willmer P (2005) Role of nesting resources in organising diverse bee communities in a Mediterranean landscape. Ecology Entomology 30, 78-85.

Potts SG, Petanidou T, Roberts S, O'Toole C, Hulbert A and Willmer P (2006) Plant-pollinator biodiversity and pollination services in a complex Mediterranean landscape. Biology Conservation 129, 519-529.

Potts SG, Biesmeijer JC, Kremen C, Neumann P, Schweiger O and Kunin WE (2010) Global pollinator declines: trends, impacts and drivers. Trends in Ecology and Evolution 25, 345 - 353.

R Development Core Team (2011) R: A Language and Environment for Statistical Computing. R Foundation for Statistical Computing.

Ridsdill-Smith TJ (1970) The behaviour of Hemithynnus hyalinatus (Hymenoptera: Tiphiidae), with notes on some other Thynninae. Journal of the Australian Entomological Society 9, 196-208.

Swarts ND and Dixon KW (2009) Terrestrial orchid conservation in the age of extinction. Annals of Botany 104, 543-556.

Thomson JD (1981) Spatial and temporal components of resource assessment by flower-feeding insects. Journal of Animal Ecology 50, 49-59.

Tremblay RL, Ackerman JD, Zimmerman KK and Calvo RN (2005) Variation in sexual reproduction in orchids and its evolutionary consequences: a spasmodic journey to diversification. Biological Journal of the Linnaean Society 84, 1-54.

Vanbergen AJ and the Insect Pollinators Initiative (IPI) (2013) Threats to an ecosystem service: pressures on pollinators. Frontiers in Ecology and the Environment, 11(5), 251-259.

Westphal C, Steffan-Dewenter I, and Tscharntke T (2006) Bumblebees experience landscapes at different spatial scales: possible implications for coexistence. Oecologia 149(2), 289-300.

Whelan RJ, Rodgerson L, Dickman CR and Sutherland EF (2002) Critical life cycles of plants and animals: developing a process based understanding of population changes in fire-prone landscapes. In 'Flammable Australia: The fire regimes and biodiversity of a continent' (Eds RA Bradstock, JE Williams, AM Gill) pp. 94-124. (Cambridge University Press: Cambridge). 